\title{
WAUKAUYENGTIPU AND UCHII RIVER UPLANDS EXPEDITION 2019 - REPORT WITH PHOTOGRAPHIC OBSERVATIONS OF CARNIVOROUS FLORA OF THE PARUIMA TERRITORY IN THE CUYUNI-MAZARUNi REgion OF GUYANA
}

Mateusz WrazidLo • Department of Fundamentals of Machinery Design • Faculty of Mechanical Engineering • Silesian University of Technology • Konarskiego 18a • 44-100 Gliwice • Poland • matwraz@gmail.com•https://orcid.org/0000-0001-5383-1906

Keywords: Guiana Highlands, Waukauyengtipu, tepui, Guiana Shield, Pantepui, carnivorous plants, Uchii River, Gran Sabana.

Abstract: An expedition to the territory of Paruima and its vicinities was organized between January $3-12,2019$. The objective was to visit the areas belonging to the Guyanese outreach of the Gran Sabana (Eng. "Great Savanna") in the vicinity of the Uchii River (aka Utshi River) near the Venezuelan border and to reach the underexplored summit of the Waukauyengtipu plateau. The aim of the expedition was to make botanical observations with the main focus of reviewing local carnivorous plant species occurrences, as well as to assess the feasibility of the area for carrying out future scientific research and implementing small-scale eco-tourism activities in the territories belonging to the Pemón Arekuna community of Paruima. The expedition resulted in making interesting observations regarding the unique flora of the Guiana Highlands found around the areas of the Uchii River uplands in the Gran Sabana and on Waukauyengtipu.

\section{Introduction}

An expedition to the territory of Paruima and its vicinity was organized between January 3-12, 2019. The objective was to visit the areas belonging to the Guyanese outreach of the Gran Sabana (Eng. "Great Savanna") in the vicinity of the Uchii River (aka Utshi River) and Uchii Falls (aka Utshi Falls) near the Venezuelan borderline and to reach the underexplored summit of the Waukauyengtipu plateau.

The aim of the expedition was to make photographic botanical observations with the main focus being reviewing local carnivorous plant species occurrences, as well as to assess the feasibility of the area for carrying out possible future scientific research and implementing small-scale ecotourism activities in the territories belonging to the Pemón Arekuna community of Paruima.

The areas surrounding Paruima offer access to large expanses of premontane and montane primary tropical forest. In addition, shrub savannas and savanna/forest mosaic areas are in close proximity to Uchii Falls and the Venezuelan borderline marked by the so-called Schomburgk Line. Paruima and its vicinity also offer a number of habitats associated with the summits of the tepuis (Kelloff et al. 2011, pp. 25-29), or the Pantepui biogeographical region in general, most notably on the summit areas of Waukauyengtipu. Waukauyengtipu is a table mountain situated close to the western border of Guyana marked by the course of the Venamo (aka Wenamu) River (Anderson 2003 ) and the northwestern end of the so-called Schomburgk Line, and is one of the highest mountains in Guyana (Kelloff et al. 2011, pp. 44-46).

The expedition was co-organized independently by the author of this paper in collaboration with Darrell Carpenay, a Guyanese photographer. The team consisted of four people accompanied by members of the Indigenous Pemón Arekuna community of Paruima:

- Mateusz Wrazidlo - co-organizer and lead coordinator,

- Darrell Carpenay - co-organizer and photographer, 
- Orson Hinds - logistics coordinator and expedition chef,

- Izabela Stachowicz - biologist and scientific consultant,

- Alex Smith - guide for Uchii Falls and Waukauyengtipu,

- Calio Elliman - guide for Waukauyengtipu and local plant expert,

- Charlie Elliman - assistant guide for Waukauyengtipu.

The organizational process for visiting the area was coordinated by Lee Williams (Toshao of Paruima) and Lennox Percy (vice-Toshao of Paruima).

Materials and methods

A survey in Region 7, Cuyuni-Mazaruni in Guyana was carried out during an expedition organized in January 2019. The methodology was based on making in-situ observations, supplemented by preparing photographic documentation of a number of carnivorous plant habitats encountered along the trekking path. In total, 5 perimeters were visited and documented, as listed in Table 1. Plant photographs were made using a digital camera equipped with a zoom lens (Olympus OM-D E-M5 mk.II + Panasonic Leica DG Vario-Elmarit 12-60 mm f/2.8-4 ASPH). Taxonomic identification of the documented specimens was based on a morphological analysis according to Taylor

\begin{tabular}{|c|c|c|c|c|}
\hline No. & Observation perimeter name & $\begin{array}{l}\text { Approx. } \\
\text { coordinates }\end{array}$ & $\begin{array}{l}\text { Approx. } \\
\text { elevation } \\
\text { [m a.s.1.] }\end{array}$ & $\begin{array}{l}\text { Carnivorous plant } \\
\text { species observed }\end{array}$ \\
\hline 1 & Savannas around Uchii Falls & $\begin{array}{l}5^{\circ} 41^{\prime} 11.9^{\prime \prime} \mathrm{N} \\
61^{\circ} 06^{\prime} 44.4^{\prime \prime} \mathrm{W}\end{array}$ & $860-900$ & $\begin{array}{l}\text { Catopsis berteroniana } \\
\text { Drosera kaieteurensis } \\
\text { Utricularia amethystina } \\
\text { Utricularia longeciliata } \\
\text { Utricularia trichophylla } \\
\text { Utricularia pubescens } \\
\text { Utricularia hispida }\end{array}$ \\
\hline 2 & $\begin{array}{l}\text { Mosaic forest \& savannas } \\
\text { leading to Venezuelan border }\end{array}$ & $\begin{array}{l}5^{\circ} 40^{\prime} 21.5^{\prime \prime} \mathrm{N} \\
61^{\circ} 07^{\prime} 12.1^{\prime \prime} \mathrm{W}\end{array}$ & $900-1000$ & $\begin{array}{l}\text { Brocchinia reducta } \\
\text { Catopsis berteroniana } \\
\text { Drosera felix } \\
\text { Utricularia hispida } \\
\text { Utricularia jamesoniana } \\
\text { Utricularia pusilla } \\
\text { Utricularia subulata }\end{array}$ \\
\hline 3 & $\begin{array}{l}\text { Trail from Ararata Camp to } \\
\text { Waukauyengtipu wall }\end{array}$ & $\begin{array}{l}5^{\circ} 49^{\prime} 37.6^{\prime \prime} \mathrm{N} \\
61^{\circ} 08^{\prime} 40.0^{\prime \prime} \mathrm{W} \\
-5^{\circ} 49^{\prime} 41.4^{\prime \prime} \mathrm{N} \\
61^{\circ} 11^{\prime} 40.8^{\prime \prime} \mathrm{W}\end{array}$ & $890-1350$ & $\begin{array}{l}\text { Utricularia } \text { cf. alpina } \\
\text { Utricularia jamesoniana }\end{array}$ \\
\hline 4 & $\begin{array}{l}\text { Waukauyengtipu summit - } \\
\text { vicinities of Camp Misery }\end{array}$ & $\begin{array}{l}5^{\circ} 49^{\prime} 48.1^{\prime \prime} \mathrm{N} \\
61^{\circ} 12^{\prime} 32.7^{\prime \prime} \mathrm{W}\end{array}$ & $1430-1510$ & $\begin{array}{l}\text { Utricularia } \text { cf. alpina } \\
\text { Utricularia jamesoniana }\end{array}$ \\
\hline 5 & $\begin{array}{l}\text { Waukauyengtipu summit - } \\
\text { Stegolepis wetland }\end{array}$ & $\begin{array}{l}5^{\circ} 49^{\prime} 56.9^{\prime \prime} \mathrm{N} \\
61^{\circ} 14^{\prime} 05.9^{\prime \prime} \mathrm{W}\end{array}$ & 1450 & $\begin{array}{l}\text { Brocchinia reducta } \\
\text { Heliamphora heterodoxa } \\
\text { Drosera roraimae } \\
\text { Drosera kaieteurensis }\end{array}$ \\
\hline
\end{tabular}


(1989) for Lentibulariaceae, McPherson et al. (2011) for Sarraceniaceae, Robinson et al. (2017) for Droseraceae, and Holst (1997) for Bromeliaceae. Elevation data and coordinates were collected using a GPS device (Garmin Oregon 750t).

The locations chosen for the undertaking were the Uchii River uplands in the Guyanese part of the Gran Sabana and the plateau of Waukauyengtipu, which until this day remains one of the underexplored areas of the Guiana Highlands (Huber 1995). The Uchii River uplands were studied botanically in the past, most notably during three expeditions being parts of the Smithsonian Biological Diversity of the Guiana Shield Program. The first expedition was led by Tim McDowell and took place in May 1990 (Hollowell et al. 2004). The other ones were led by H. David Clarke, between January-February 1996 (Kelloff et al. 2011, pp. 25-29) and June-July 1997 (Kelloff et al. 2011, pp. 44-46). H. David Clarke's 1997 expedition also includes the only recorded visit to the Waukauyengtipu plateau prior to the expedition hereby reported.

Fieldwork report

Part 1 - Uchii River Uplands

\section{Thursday, January 3}

The team assembled at the Ogle Airport in Georgetown, Guyana at 7:00 AM and boarded a charter plane (BN-2 Islander reg. no. 8R-GHM) operated by Trans Guyana Airways at 1:00 PM, following a short delay dictated by unfavorable weather conditions. The plane arrived in Paruima shortly before 2:30 PM. The team members were accommodated in a local health post to prepare for the upcoming trekking activities. A meeting was organized with the Community Council. The residents of the village were presented with a short presentation about the plans for the expedition. Consultations were carried out regarding the itinerary for the following days. Guides were introduced to the team.

\section{Friday, January 4}

The group left Paruima shortly before 7:00 AM and advanced southwards after crossing the Kamarang River, following a forested trail leading to Uchii Falls accompanied by a local guide, Alex Smith. The trail was muddy and steep which eventually contributed to a much-delayed arrival at the final destination. The team left the rainforest and entered the Gran Sabana areas dominated by a notable abundance of Pteridium sp. ferns at approx. 4:15 PM. Continuing their walk towards the Uchii Falls campsite, at approx. 4:35 PM the group arrived at the bank of the Uchii River, which required traversing. Due to high water levels and a strong current, crossing the river proved to be much more time consuming and hazardous than expected, forcing a decision to use a nearby Pemón household as an emergency campsite for the night, instead of proceeding to the initially planned campsite by the Uchii Falls cliffside.

First carnivorous plant populations were observed:

- Utricularia trichophylla - found in a shallow stream right after entering the savanna, shortly after leaving the forest (Fig. 1A, 1B)

- Utricularia pubescens - nearby U. trichophylla populations described above (Fig. 1C)

- Utricularia hispida - as above (Fig. 1I)

- Drosera kaieteurensis - on the banks of the Uchii River on exposed peat patches

- Catopsis berteroniana - present in large numbers, growing epiphytically on shrubs and trees around the banks of the Uchii River (Fig. 1F) 


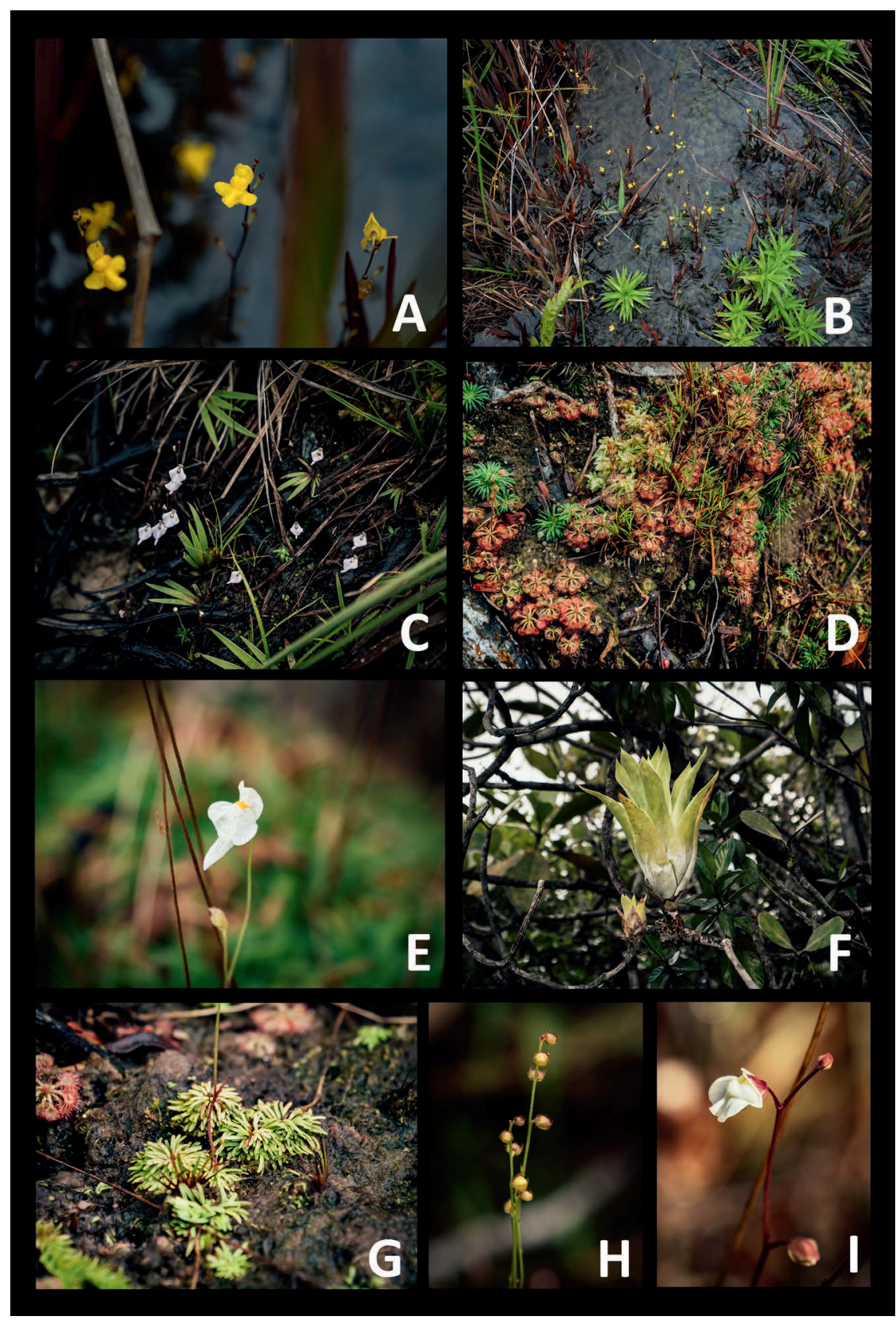

Figure 1: Carnivorous plants observed around the Uchii Falls savannas (observation perimeter No. 1): A) Utricularia trichophylla - inflorescence; B) Utricularia trichophylla colony in a stream; C) Utricularia pubescens; D) Drosera kaieteurensis; E) Utricularia amethystina; F) Catopsis berteroniana; G) Utricularia longeciliata; H) Utricularia longeciliata - flowerstalk; I) Utricularia hispida. 
Saturday, January 5

Saturday was spent mostly on botanical exploration of the Uchii Falls areas and savanna/forest mosaic vegetation areas extending towards the Venezuelan border. The camp was moved and set up nearby the Uchii Falls cliffside at approx. 10:00 AM. Further carnivorous plant observations were made on the bank of the Uchii River, right behind the Uchii Falls cliff zone:

- Utricularia pubescens

- Utricularia amethystina (Fig. 1E)

- Utricularia longeciliata (Fig. $1 \mathrm{G}, 1 \mathrm{H}$ )

- Drosera kaieteurensis (Fig. 1D)

Carnivorous plant occurrences observed around the Uchii Falls savannas (observation perimeter No. 1) are presented in Figure 1.

Walking towards the Venezuelan border other carnivorous plant species were found in a patch of mid-elevation loose forest vegetation typical to the Gran Sabana areas (at the elevation of approx. 900-1000 m a.s.1.) with a notable presence of Stegolepis angustata, Saxofridericia regalis, Clusia sp., and myrmecophytic members of the Melastomataceae family. These species include:

- Utricularia jamesoniana (Fig. 2C)

- Utricularia pusilla (Fig. 2A, 2B)

- Brocchinia reducta (Fig. 2D)

- Catopsis berteroniana (Fig. 2H)

The team continued to walk until they reached the last settlement on the Guyanese side of the border in an open, sandy savanna area approx. $1 \mathrm{~km}$ from the Venezuelan border. The place turned out to be a good lookout spot, providing an unobstructed view over the Ilu-Tramen Massif and the Venezuelan part of the Gran Sabana (Fig. 3) leading towards the Pemón Arekuna village of Wuarapata.

The vegetation consisted mostly of open grassland dominated by Axonopus anceps with patches of various shrubs. Carnivorous plants found by the end of the trail included:

- Drosera felix - present on the trail in moist, sandy areas

- Utricularia subulata - in shallow pools alongside the trail

- Utricularia hispida - frequent yet scattered occurrences among clumps of Axonopus anceps

- Catopsis berteroniana - growing abundantly on short trees and shrubs (Fig. 2G) visible all around the perimeter of observation

Walking back to the Uchii Falls campsite the weather cleared up looking northwest, providing a view over the southeastern cliffs of the Waukauyengtipu massif. Campsite was reached at approx. 3:30 PM.

Carnivorous plant occurrences observed around the mosaic forest and savannas leading to the Venezuelan border (observation perimeter No. 2) are presented in Figure 2.

Sunday, January 6

Sunday was dedicated entirely to a return trekking to Paruima. The team cleaned up and left the campsite at approx. 7:00 AM and started walking north towards the village. At 8:15 AM, a junction of Uchii and Kamarang rivers was reached and crossed using an improvised raft. The group took a detour to reach the Uchii Falls gorge to see the waterfall from below, arriving under the cliffs at approx. 9:20 AM (Fig. 4). Due to difficult, muddy conditions on the trail combined with the overall fatigue of the team members, the return trek finished in Paruima shortly after 6:00 PM. 


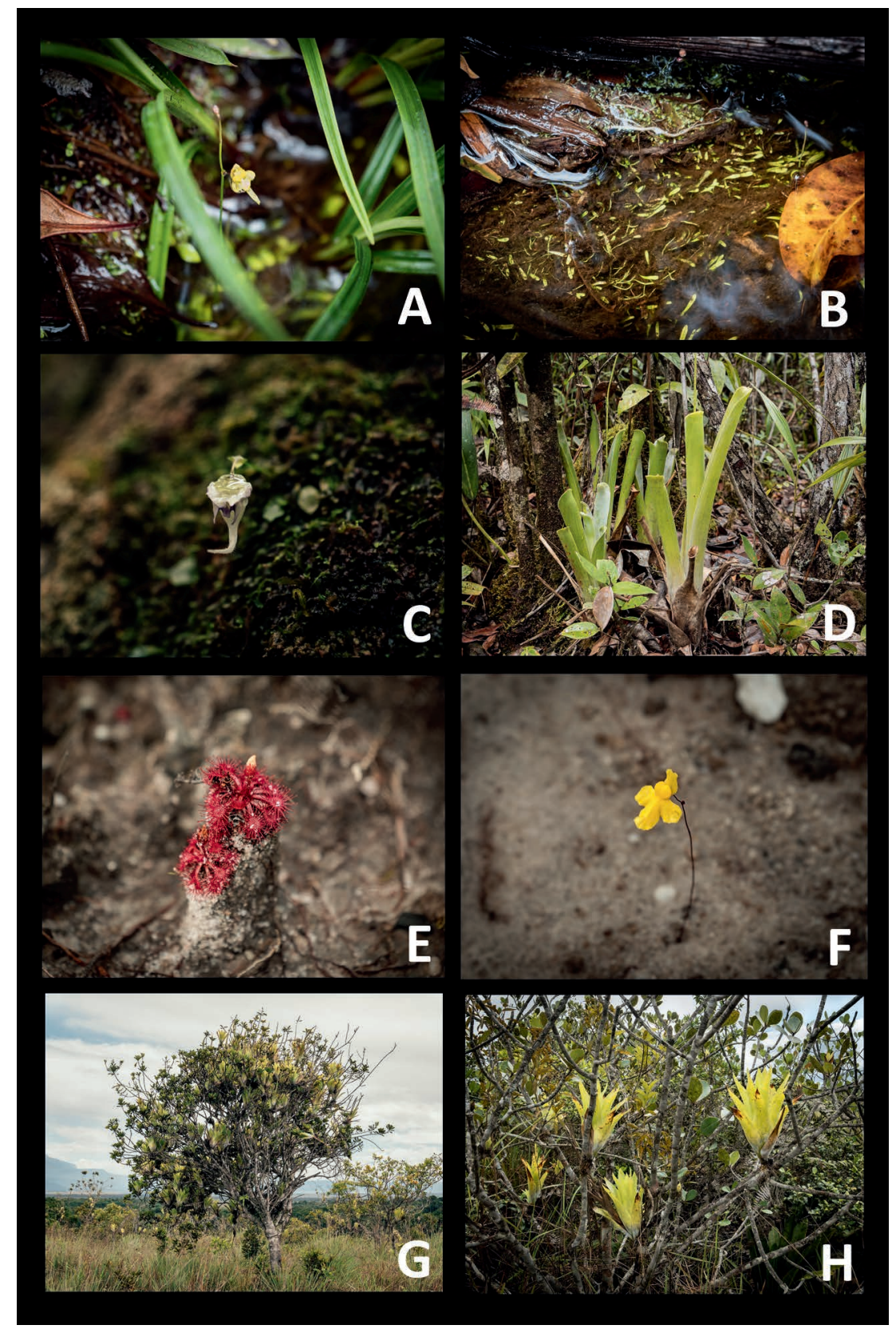

Figure 2: Carnivorous plants observed around the mosaic forest and savannas leading to the Venezuelan border (observation perimeter No. 2): A) Utricularia pusilla - inflorescence; B) Utricularia pusilla colony in a stream; C) Utricularia jamesoniana; D) Brocchinia reducta; E) Drosera felix; F) Utricularia subulata; G) Tree overgrown by a colony of Catopsis berteroniana; $\mathrm{H}$ ) Catopsis berteroniana. 


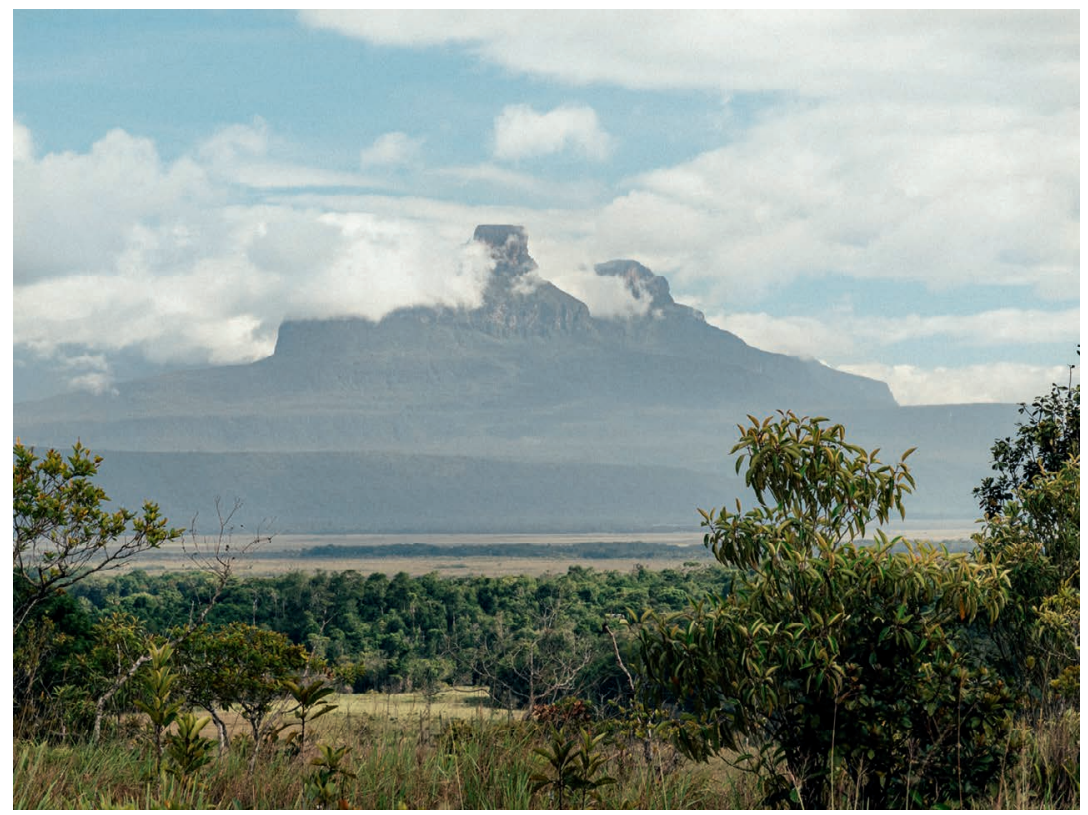

Figure 3: Tramen-tepui and Ilu-tepui seen from the Guyanese side of the Gran Sabana, 540'12.9"N 6107'41.9"W, elev. ca. 995 m a.s.I.

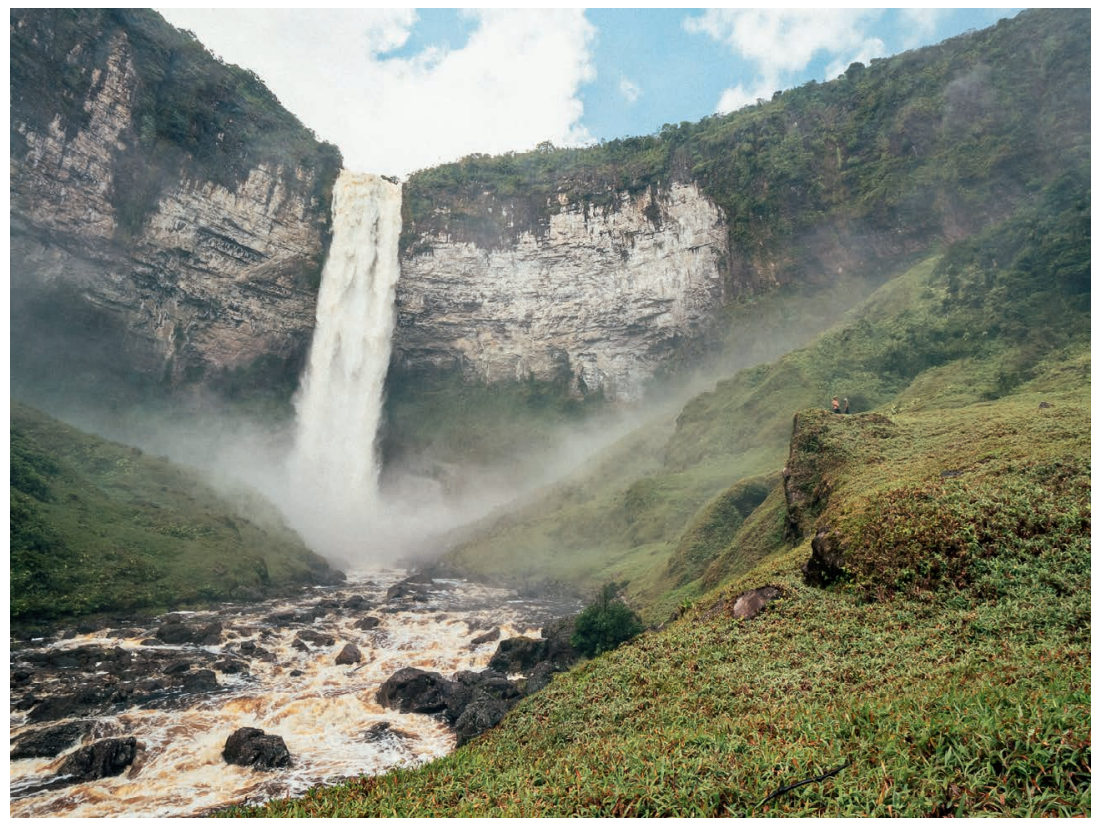

Figure 4: Uchii Falls seen from the bottom of the Uchii River gorge. $5^{\circ} 41^{\prime} 25.5^{\prime \prime} \mathrm{N}$ 6106'36.6"W, elev. ca. $620 \mathrm{~m}$ a.s.I. 
Monday, January 7

After meeting the guides to accompany the group during the second part of the expedition - the ascent of Waukauyengtipu - a boat was used to cross the Kamarang River at approx. 10:00 AM. The trail led westwards and ended with a lower cloud forest right before turning into a patch of sandy plain with scrub vegetation (elevation approx. $890 \mathrm{~m}$ a.s.1.) where the campsite was located. The forest was characterized by an abundance of epiphytes, such as Philodendron insigne plants, members of the Bromeliaceae family, Rapataea steyermarkii, and many epiphytic orchids. The first occurrence of a carnivorous plant was confirmed, namely Utricularia jamesoniana (Fig. 8A). The campsite, called "Ararata" in the Pemón Arekuna language (meaning exactly "a forest which is not dense" according to Calio Elliman) was reached shortly after 3:00 PM. The campsite provided a clear view over the eastern wall of Waukauyengtipu (Fig. 5).

Tuesday, January 8

The group left the campsite before 8:00 AM and advanced westwards towards the eastern wall of Waukauyengtipu. On the way to the wall, at the elevation of approx. $1330 \mathrm{~m}$ a.s.l. populations of Utricularia cf. alpina were found growing epiphytically on the tree branches. The base of the tepui wall was reached shortly before 1:00 PM, the area right underneath the wall was a wet, boggy ridge. Reaching the summit of the plateau required climbing a vertical, densely vegetated part of the trail

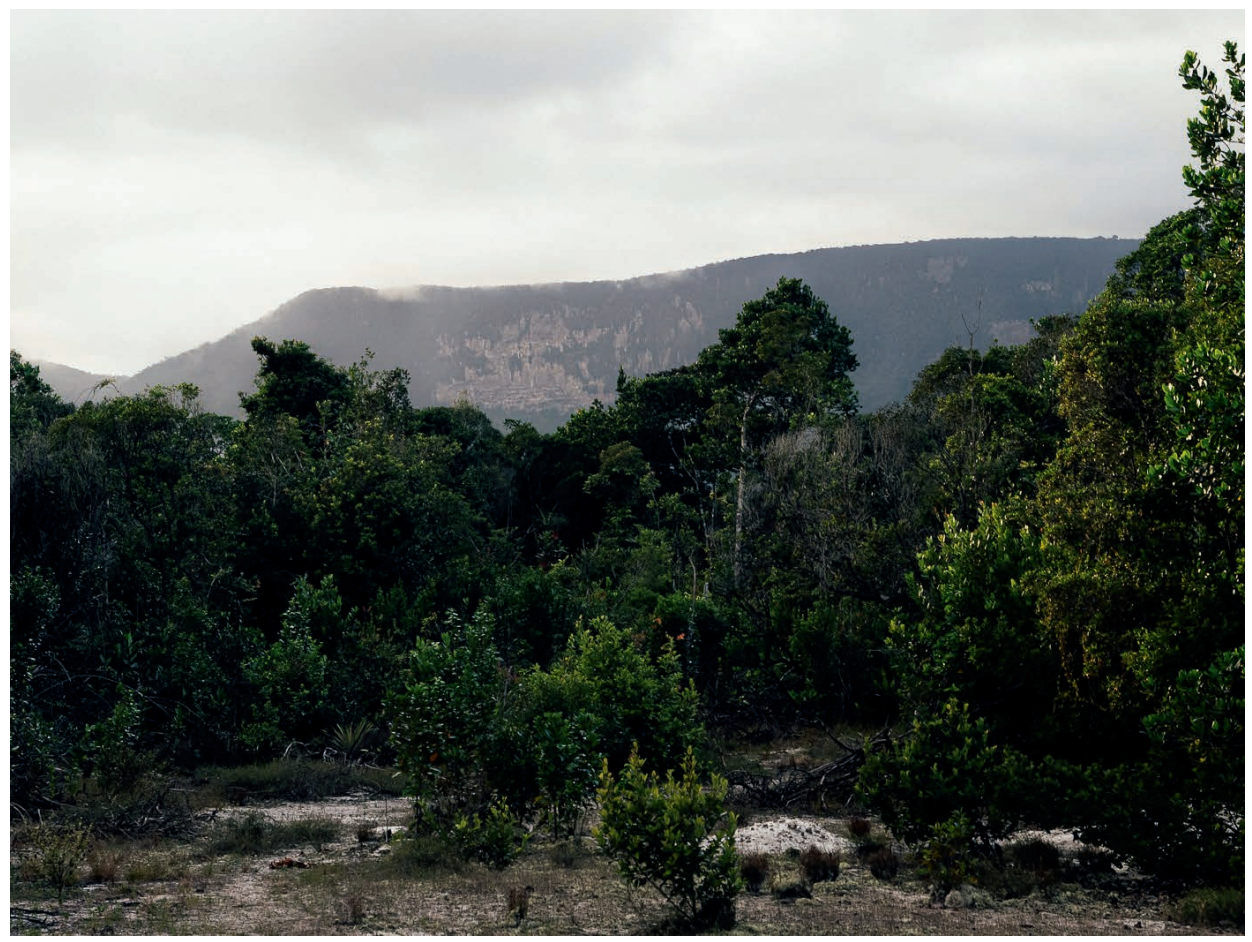

Figure 5: Wall of Waukauyengtipu seen from the Ararata Camp. 549'37.6"N 6108'40.0'W, elev. ca. 890 m a.s.l. 


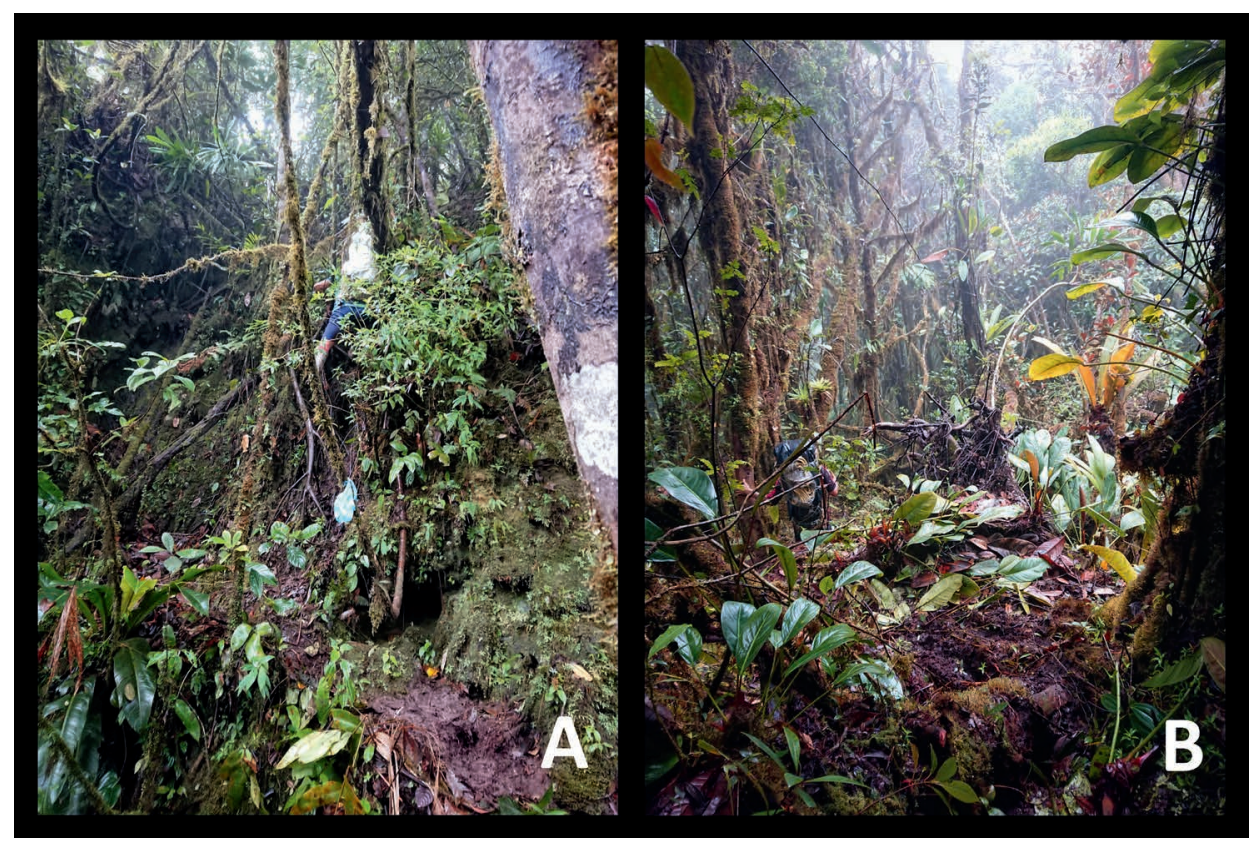

Figure 6: Highlights from the trail to Waukauyengtipu summit: A) Alex Smith crossing over the vertical part of the "Clarke's Pass", approx. elev. 1430 m a.s.I.; B) Cloud forest on the summit of Waukauyengtipu.

(dubbed "Clarke's Pass", referring to the descriptions left by the leader of the 1997 Smithsonian Expedition) using only exposed roots (Fig. 6A). The summit of Waukauyengtipu turned out to be covered by a dense, damp Pantepui cloud forest (Fig. 6B). After walking approx. $1.8 \mathrm{~km}$ across the summit plateau, the campsite, called "Camp Misery" due to its cold and wet surroundings at the elevation of approx. $1510 \mathrm{~m}$ a.s.1., was reached at approx. 3:30 PM.

Wednesday, January 9

On Wednesday the group split into two smaller teams - Darrell, Orson and Izabela retreated back to camp Ararata, while Mateusz and Calio left the campsite before 7:00 AM and continued westwards, followed by Alex and Charlie, with the objective to push towards one of the scattered open peat wetland vegetation areas on the summit of Waukauyengtipu. The summit turned out to be a densely vegetated, swampy area which was exceptionally laborious to penetrate, and characterized by an abundance of plants typical to the Pantepui cloud forest vegetation, such as Brocchinia tatei, Brocchinia acuminata, Guzmania squarrosa, Stegolepis cf. angustata, Clusia sp., Didymiandrum stellatum, Racinaea spiculo$s a$, and others. Carnivorous plant species found in the cloud forest included Utricularia cf. alpina (Fig. 8D) and Utricularia jamesoniana (Fig. 8C) growing epiphytically on mossy branches. A patch of peat wetland dominated by Stegolepis was found and reached shortly before 8:30 AM at the elevation of approx. $1450 \mathrm{~m}$ a.s.1. (Fig. 7) and proved to harbor many examples of interesting endemic species typical to the Guiana Highlands, including some representatives characteristic for the Pantepui montane zone (e.g. Heliamphora). Most notable findings included specimens of Orectanthe sceptrum, Bonnetia sessilis, Lindsaea stricta var. jamesoniiformis, and an abundance of exceptionally large Stegolepis ptaritepuiensis specimens. Carnivorous plants were also common, including the following species: 


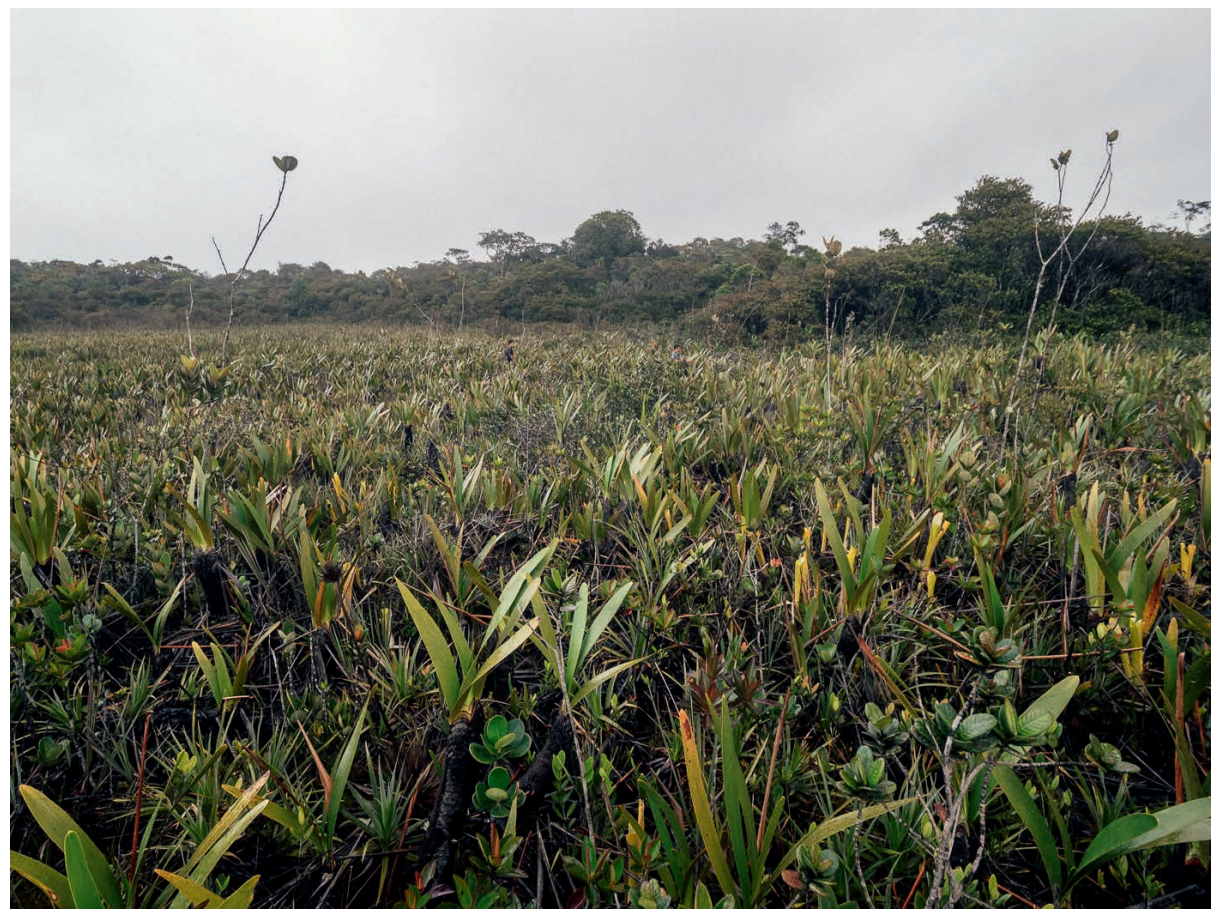

Figure 7: A patch of Pantepui montane wetland dominated by Stegolepis ptaritepuiensis on the summit of Waukauyengtipu. 549'56.9"N 61¹4'05.9"W, elev. ca. 1450 m a.s.I.

- Drosera roraimae (Fig. 8D)

- Drosera kaieteurensis (Fig. 8E)

- Brocchinia reducta (Fig. 8F)

- Heliamphora heterodoxa (Fig. 8H)

The occurrence of Heliamphora heterodoxa on the summit of Waukauyengtipu is a finding of a particular significance as it is one of just few confirmed habitats hosting a member of Sarraceniaceae recorded in Guyana up until this day.

After spending about 1 hour exploring the area, the group was forced to retreat due to rapidly declining weather conditions and started heading towards Camp Misery shortly after 9:30 AM. The campsite was reached around 11:00 AM and cleaned up, then everyone continued moving eastwards to descend the mountain. Camp Ararata was reached at approx. 4:00 PM.

\section{Thursday, January 10}

Thursday was spent entirely on descending the trail back to Paruima. The Ararata campsite was cleaned and left before 10:00 AM and the group arrived in Paruima at approx. 2:15 PM.

\section{Friday, January 11}

On Friday, a briefing was held with the members of the Community Council of Paruima in order to share the results of the expedition. The group left Paruima by boat at 9:30 AM, accompanied by Lee Williams and Lennox Percy, as well as a boat operator. After stopping twice to see waterfalls going down the Kamarang River (Iobaru Falls - $5^{\circ} 49^{\prime} 58.5^{\prime \prime} \mathrm{N} 61^{\circ} 00^{\prime} 51.6^{\prime \prime} \mathrm{W}$ and Apurwayak Falls $-5^{\circ} 50^{\prime} 38.2^{\prime \prime} \mathrm{N}$ $60^{\circ} 59^{\prime} 38.6^{\prime \prime}$ ) and a brief pause in Waramadong, the team reached Kamarang before 4:30 PM. 


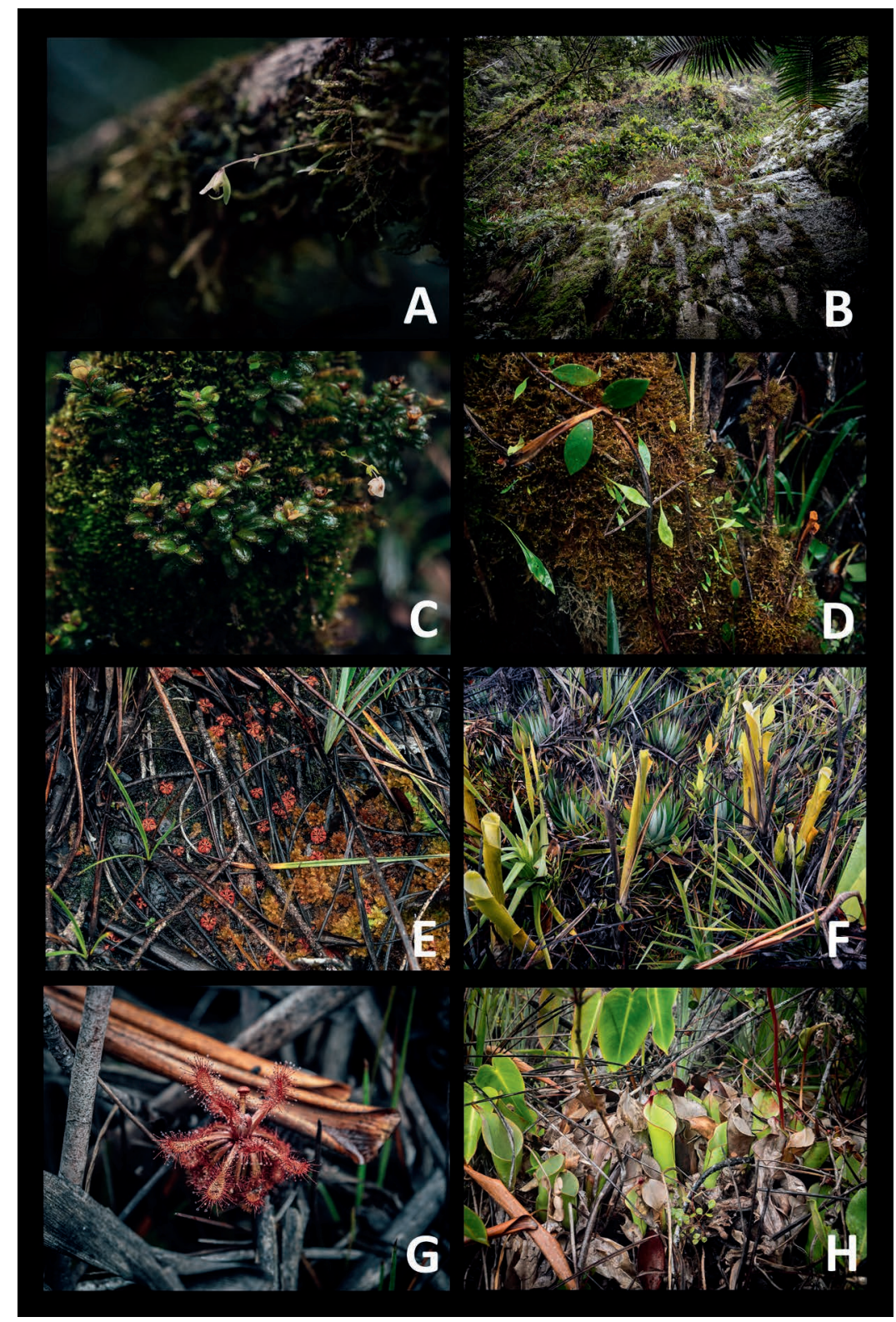

Figure 8: Carnivorous plants observed during the trek to Waukauyengtipu summit (observation perimeter No. 3, No. 4, and No. 5). A) Utricularia jamesoniana-found near Ararata Camp; B) Wall of Waukauyengtipu covered by vegetation; C) Utricularia jamesoniana on the summit of Waukauyengtipu, growing among a clump of Macrocentrum minus; D) Utricularia cf. alpina; E) Drosera kaieteurensis; F) Brocchinia reducta on the summit peat wetland, growing with Orectanthe sceptrum; G) Drosera roraimae; H) Heliamphora heterodoxa. 


\section{Saturday, January 12}

The expedition was concluded with a return flight from Kamarang to Georgetown in the morning.

Summary of carnivorous plant observations recorded during the expedition

In total, 5 perimeters were documented. 15 species of carnivorous plants, belonging to 4 different families, were observed (Table 1).

\section{Conclusions}

Paruima and its vicinities proved to be a promising ground for future scientific and eco-tourism activities. Thanks to the high abundance of unique species of flora, the area is characterized by extraordinary opportunities for scientific research and educational projects. As for the plateau of Waukauyengtipu, although it may be a relatively small geographical feature that is overshadowed by much larger and more famous mountains in the region (e.g., Mount Roraima), it is no less interesting, not least, since it still remains very little known to this day, especially in terms of the biodiversity that it harbors. Further botanical surveying and other research undertakings are required to fully understand the biodiversity present in the vicinity of Paruima.

Acknowledgements: Members of the Pemón Arekuna community of Paruima, especially Calio Elliman, Chris Elliman, Alex Smith, Lee Williams, and Lennox Percy, as well as others who contributed to the project, are thanked for their hospitality, assistance and guidance during the January 2019 expedition. Fernando Rivadavia is thanked for his help provided with the taxonomic identification of specimens observed during the expedition, especially members of the genus Utricularia.

\section{References}

Anderson, E.W. 2003. International Boundaries: A Geopolitical Atlas. New York: Routledge. pp. $356 ; 879$.

Hollowell, T., McDowell, T., Funk, V.A., Kelloff, C.L., and Gopaul, D. 2004. Smithsonian Plant Collections, Guyana: 1990 - 1991, Tim McDowell. Smithsonian Institution, Contributions from the United States National Herbarium; 50, pp. 24-30. http://www.jstor.org/stable/23493110

Holst, B. 1997. Bromeliaceae. In: Steyermark, J.A., Berry, P.E., Holst, B.K., editors. Flora of the Venezuelan Guayana. Volume 3. Araliaceae-Cactaceae. St. Louis, Missouri Botanical Garden: Timber Press.

Huber, O. 1995. Geography and physical features. In: Steyermark, J.A., Berry, P.E., Holst, B.K., editors. Flora of the Venezuelan Guayana. Volume 1. Introduction. St. Louis, Missouri Botanical Garden: Timber Press. pp. 36-37; 60-61.

Kelloff, C.L., Alexander, S.N., Funk, V.A., and Clarke, H.D. 2011. Smithsonian Plant Collections, Guyana: 1995-2004, H. David Clarke. Smithsonian Contributions to Botany 97. https://doi. org/10.5479/si.0081024X.97.1

McPherson, S., Wistuba, A., Fleischmann, A., and Nerz, J. 2011. Sarraceniaceae of South America. Redfern Natural History Productions Ltd.

Robinson, A., Gibson, R., Gonella, P., McPherson, S., Nunn, R., and Fleischmann, A. 2017. Drosera of the World, Volume 3: Latin America \& Africa. Redfern Natural History Productions Ltd.

Taylor, P. 1989. The Genus Utricularia: A Taxonomic Monograph. London: HMSO, Royal Botanic Gardens, Kew. 